Piotr Kowzan

https://doi.org/10.26881/ae.2019.16.11

ORCID: 0000-0002-6506-8327

Uniwersytet Gdański

piotr.kowzan@ug.edu.pl

\title{
Współautorstwo: wyzysk i współpraca (ze studentami)
}

\section{Problem współautorstwa}

Widoczność jest miarą autorytetu w nauce. Awans w nauce zależy wciąż głównie od prac indywidualnych (prace licencjackie, magisterskie, dysertacje doktorskie, dorobek do habilitacji oraz nominacje profesorskie). $Z$ kolei decyzje o finansowaniu badań zależą w większym stopniu od liczby publikacji (produktywność danej osoby) i cytowań (użyteczność publikacji dla innych badaczy). W pracach jednego autora podpisana osoba jest odpowiedzialna za całość. Można ją zaprosić i porozmawiać z nią o całości dzieła. Z kolei w pracach wieloautorskich kolejny współautor o całej pracy może wiedzieć niewiele, a nawet w samej dyscyplinie może występować zaledwie gościnnie. Marek Kwiek (2019a) twierdzi, że naukę mierzy się i ocenia ilościowo. To, co mierzone i oceniane, to głównie autorstwo - jego występowanie w czasie (produktywność) i przestrzeni (prestiż miejsca) (Kwiek 2019a). Stało się ono towarem, ponieważ: a) stało się miarą wkładu pracy naukowców, b) przekłada się na możliwości finansowania badań według reguł prestiżu i c) ma wartość użytkową, gdyż umożliwia innym badaczom powoływanie się na dotychczasowe wyniki badań. Problem współautorstwa jest nierozerwalnie związany z kwestią utowarowienia. Dodatkowo jednak odsłania problemy podziału pracy w hierarchicznie zorganizowanych strukturach instytucji uniwersytetu. Nie jest łatwo zacząć współpracować, gdyż choć jest to korzystny sposób organizacji pracy, to jednak nie jest sposobem domyślnym. Pia Hurmelinna-Laukkanen i jej zespół (2019) pokazują, że na początku współpracy trzeba ponieść pewne koszty zwane transakcyjnymi. Są one związane z jej ustanowieniem (dobór osób i środków komunikacji), zarządzaniem (uzgadnianie harmonogramu spotkań i podziału zadań) i z pracą afektywną, czyli wysiłkiem na rzecz tego, żeby ludziom o różnych motywacjach było razem dobrze (zob. Hardt 2012). Współpraca wymaga także uzgodnień merytorycznych, czyli 
językowych, terminologicznych i metodologicznych. Jest to na tyle trudne, że łatwiej polegać na znajomych niż zawiązywać współpracę od nowa - zwłaszcza ze studentami, którzy stanowią źródło dodatkowej niepewności. Dlatego na kwestię współautorstwa (jako procesu współpracy, którego ukoronowaniem jest publikacja) spojrzymy w tym artykule z newralgicznej dla uniwersytetu perspektywy, czyli uwzględniającej studentów. Perspektywa uwzględniająca nowych członków zespołu jest ważna - choć interakcje w grupie odbywają się na ogół w małej skali, to dotyczą reprodukcji kultury organizacyjnej uniwersytetu i jego dyscyplinarnych subkultur wśród kolejnych pokoleń badaczy. Chodzi tu o kultury i subkultury organizacyjne rozumiane jako zespół norm i przekonań na temat ludzi, istotnych w danej organizacji wartości i praktyk-artefaktów w jakimś stopniu ucieleśniających te normy i wartości (Jeran, Basińska 2020). Dotychczasowe badania dowodzą, że to właśnie młodzi naukowcy - niezależnie od dyscypliny - doświadczają więcej negatywnych skutków współpracy niż bardziej doświadczeni (Tsai et al. 2016).

Celem artykułu jest identyfikacja takich rozwiązań organizacyjnych w zakresie współpracy badawczej ze studentami, które byłyby etyczne z perspektywy późniejszego współautorstwa artykułów i korzystne zarówno dla studentów, jak i pracowników naukowo-dydaktycznych. Nierówny status osób zaangażowanych w badania stwarza pole do nieporozumień i nadużyć, takich jak pominięcie wkładu pracy studentki czy odbieranie jej głównego autorstwa publikacji. Wyzysk, czyli zagarnianie owoców czyjejś pracy, nie musi być brutalnym rugowaniem z grona współtwórców. Studenci nie zawsze zdają sobie sprawę ze skali udzielonej pomocy $\mathrm{w}$ badaniach i w związku z tym nie oczekują takiej formy uznania. Współpraca ze studentami w zakresie wspólnych publikacji jest więc obszarem, w którym trudno określić, na ile ich widoczność w gronie współautorów artykułu jest skutkiem ich emancypacji, a na ile wyzysku lub - przeciwnie - szczodrości bardziej doświadczonych współpracowników. Udział studentów w zespołach badawczych związany jest z ich wykroczeniem poza zwyczajną aktywność podczas zajęć, więc relacje mogą mieć charakter nieformalny lub - przeciwnie - ten udział może być zaplanowany w ramach realizacji przygotowanego pod tym kątem projektu (Deesomsak et al. 2014). Wprawdzie zaangażowanie w badania i w publikowanie to odrębne obszary aktywności naukowej (Hurmelinna-Laukkanen et al. 2019), to jednak studentom byłoby trudno publikować bez udziału w badaniach.

Publikacje analizujące kulisy powstawania artykułów wieloautorskich ograniczają się do opisu możliwych patologii związanych z autorstwem badań i artykułów (np. Naezer, Benschop, van den Brink 2019; Sikes 2009), walką o standardy etyczne (Goodyear, Crego, Johnston 1992; Min 2019) oraz opisów uwarunkowań relacji doktorantów z promotorami (Brabazon 2016; Costa, Gatz 1992). Podtrzymywana jest waga związku badań z nauczaniem na uniwersytecie (Robertson 2007; Tight 2016), choć brakuje opisu sposobów tego, jak mogłaby wyglądać współpraca ze studentami w zakresie wspólnie prowadzonych i publikowanych badań (Mercer-Mapstone et al. 2017). Relacje uwzględniające proces powstawania tekstu w takiej 
współpracy ograniczają się na ogół do sytuacji, w których metodologia badania była studentom zadana i nie współdecydowali oni o niej. Szczególnie zasłużone i wyczulone na niuanse komunikacyjne we współpracy ludzi nierównych są badania etnograficzne (Szwabowski, Wężniejewska 2017) oraz analizy prowadzone w nurcie badań w działaniu (Červinková 2013).

Meandry politycznej ekonomii, stojącej za wyceną publikacji (Bruno 2014; Szadkowski 2015) interesują studentów o tyle, o ile rozważają oni dołączenie do grona badaczy, choćby poprzez studia trzeciego stopnia. Zostanie podczas studiów pierwszego lub drugiego stopnia współautorką/-em publikacji może dać przewagę nad rówieśnikami i stanowi potwierdzenie eksperckiej wiedzy w danym zakresie. Dzieje się tak przede wszystkim dlatego, że okres przygotowywania takich publikacji jest stosunkowo długi. Na wydanie artykułu brakuje zwłaszcza czasu podczas studiów trzy- i dwuletnich, szczególnie gdy najambitniejsi studenci przeplatają je dodatkowo ze stypendiami wyjazdowymi. Przykłady udanych realizacji takiej współpracy pochodzą z kół naukowych (np. Bornowska, Jendza, Zamojski 2009) oraz z ruchów społecznych (np. Mason-Deese et al. 2018), sporadycznie zaś jako oddalony w czasie efekt zajęć fakultatywnych (Kowzan et al. 2018). Zwykle nawet współpraca w ramach seminarium dyplomowego nie wytrzymuje próby czasu i po obronie pracy dyplomowej trudno jest absolwentom przekuć wyniki swojego dorobku badawczego na artykuł naukowy.

W niektórych dyscyplinach możliwość znalezienia się studentów, także tych trzeciego stopnia, w gronie współautorów publikacji może być utrudniona ze względu na wciąż niewielką liczbę badań prowadzonych w zespołach. Należy jednak przyjąć, że zmienia się albo ilość tego typu badań, albo dotychczasowe praktyki badawcze zaczęły być uznawane za wysiłek kolektywny, ponieważ liczba prac jednoautorskich ze wszystkich dyscyplin maleje (Ductor 2015), a liczba współtwórców rośnie (Geminiani et al. 2014). Przykładowo w pracy socjalnej „współautorstwo stało się normą w 2002 roku" (Victor et al. 2017: 2201), czyli mediana liczby autorów artykułów z osiemdziesięciu czołowych czasopism dyscypliny wzrosła wówczas do dwóch. W niektórych dziedzinach zjawisko to wynika z szerokiego zaplecza, na przykład laboratoryjnego, jakiego wymaga prowadzenie badań. Może być też pochodną metodologii danego badania, ponieważ analiza większych zbiorów danych może wymagać zaangażowania wielu osób. Zwiększanie się liczby współautorów może mieć związek z tym, że możliwość pracy na niektórych bazach danych jest czasami uzależniona od włączenia twórców tych baz do grona współautorów kolejnych badań. Warto pamiętać, że osoby, których wkład pracy nie wystarczał do uznania ich za współautorów artykułu, mogą zostać oznaczeni jako kontrybutorzy (contributors) czy współpracownicy (collaborators). Znaczenie ich wkładu może również zostać opisane w podziękowaniach (acknowledgments). Te mniej lub bardziej formalne wyrazy uznania również bywają polem konfliktów (Youtie, Bozeman 2016).

Co ciekawe, praktyki jednej dyscypliny (takie jak obecność właściciela bazy danych wśród współautorów) mogą być oburzające z perspektywy innej dziedziny. 
Warto jednak pamiętać, że znaczenie samego procesu pisania artykułu naukowego w badaniach jest zróżnicowane. Przykładowo - proces powstawania artykułu może być $\mathrm{z}$ łatwością uznany za część procesu badawczego w naukach humanistycznych i społecznych. W trakcie tworzenia spójnego tekstu może dojść do zmian w ocenie tego, co zostało zrobione $\mathrm{w}$ czasie badań. $\mathrm{W}$ rezultacie proces pisania $\mathrm{w}$ tych dziedzinach trwa zwykle dłużej niż w naukach eksperymentalnych, gdzie artykuł może mieć charakter technicznego raportowania $\mathrm{z}$ wykonanej zespołowo pracy.

Także na poziomie pojedynczego zespołu badawczego kryteria dodawania pierwszego współautora publikacji mogą różnić się od kryteriów spełnionych przez kolejnego z nich. Zróżnicowanie wkładu następnych osób może stanowić proste kryterium, według którego zespół ustali pozycję danej osoby w spisie twórców. Kryteria współautorstwa mogą też tracić na ostrości, gdy ich liczba przekroczy trzy osoby, gdyż wówczas w przypadku cytowania każdy kolejny staje się dodatkiem do pierwszego jako et al. (czyt. i inni). Wówczas współautorstwo może stać się przestrzenią gościnności, czyli na przykład dopisywania osób, które nie spełniły niektórych wytycznych autorstwa (Shaw 2011) w danej publikacji, ale dobrze rokują na duży wkład przy następnej. Bardziej doświadczeni badacze częściej niż młodsi umożliwiają studentom umieszczenie ich nazwisk w pierwszej kolejności we wspólnych artykułach, jednak sami uczniowie cenią wkład pracowników wyżej niż oni sami (Costa, Gatz 1992). Wkład dwóch osób w pracę zespołową może być na tyle znaczący, że niektórzy decydują się na wskazanie ich jako pierwszych współautorów (Moustafa 2016). Oznacza to zrównanie ich statusu w bazach danych, choć nie wpływa na wizualnie rozpoznawalną kolejność twórców. Warto zaznaczyć, że o ile perspektywa redakcji czasopisma może zamykać się na pojedynczym artykule danego numeru, o tyle sami badacze mogą myśleć seriami artykułów, zwłaszcza gdy ich pracę porządkuje harmonogram finansowanych zewnętrznie badań.

Warto jednak uwzględnić to, że twórcy są w stanie przekraczać zwyczajowe normy. Zdarza się więc dopisywanie współautorów niebędących ludźmi. Historia nauki zna przypadki dopisania kota, psa, chomika, a także trzech małp bonobo (Erren et al. 2017). Obdarować współautorstwem można również dziecko (Min 2019). Wydaje się jednak, że nie należy nikogo w ten sposób obdarowywać - czasopisma coraz częściej zastrzegają, że nie akceptują praktyk obdarowywania ( $g i f t$ authorship) i zlecania innym osobom zadania opisania wyników własnych badań (ghost autorship). Jednocześnie jednak badacze zachęcani są do ujawniania wszelkich wpływów na ich pracę - od finansowania po wkład osób trzecich.

Kwestie związane z autorstwem są pełne dylematów etycznych, szczególnie gdy dotyczą także relacji ze studentami (Goodyear, Crego, Johnston 1992). Rozstrzyganiu tych trudności przyglądają się również uczniowie, zwłaszcza gdy są częścią sprawy. To, czy uznają te rozstrzygnięcia za sprawiedliwe, może stać się kluczowe dla przebiegu ich karier akademickich. $Z$ drugiej strony spory wokół autorstwa przerażają naukowców (Smith et al. 2020), więc obawa przed posądzeniem o wyzysk może sama w sobie powstrzymywać badaczy przed wspólnym pisaniem ze studentami. 
Jeżeli przyjąć między innymi za Markiem Kwiekiem (2019b), że cechą charakterystyczną polskiego systemu szkolnictwa wyższego jest przeładowanie badaczy dydaktyką (zob. też Kowzan, Zielińska 2016), to indywidualne strategie radzenia sobie z tym obciążeniem przez pracowników mogłyby uwzględniać włączenie studiujących w proces badawczy, szczególnie w kontekście zwiększających się wymagań dotyczących produktywności naukowców. Klasyfikacji trudności w łączeniu dydaktyki z badaniami towarzyszyć będą opisy możliwych wariantów w tym zakresie.

\section{Etyczne standardy}

Warto zauważyć tempo wzrostu liczby możliwości uporządkowania współtwórców danej publikacji, gdyż jest to przyrost szybszy niż wykładniczy. Dla 2 autorów mamy 2 możliwości uporządkowania ich na liście, dla 3 - 6 możliwości, a dla 4 - tych możliwości powstaje 24 . W przypadku zespołów bardziej licznych standaryzacja w postaci kolejności alfabetycznej, nawet jeśli dotyczy porządkowania nazwisk od drugiego do przedostatniego ${ }^{1}$, znacząco redukuje liczbę możliwości porządkowania listy współautorów. Każda reguła jest jakoś niesprawiedliwa z punktu widzenia widoczności, o którą "starają się" naukowcy. Porządek alfabetyczny powoduje, że osoby z nazwiskami rozpoczynającymi się od pierwszych liter alfabetu zyskują na rozpoznawalności. Świadomość późniejszych konsekwencji uporządkowania autorów w określonej kolejności rzutuje na jakość współpracy przy danym projekcie (Kadel, Walter 2015). Ustalenie ich kolejności na podstawie wielkości wkładu pracy powoduje gęstsze sieci współpracy niż w przypadkach porządku alfabetycznego, a co więcej - prowadzi do większej liczby publikacji (Ackerman, Brânzei 2017). $\mathrm{W}$ przypadku współpracy osób o nierównym potencjale, czyli między innymi studentów z pracownikami, warto brać pod uwagę względny wkład uczestników badań, choć zorientowane na proces próby usystematyzowania takiego podejścia wytwarzają w rezultacie skomplikowane procedury (Maurer 2017).

Standardy są zwykle lokalne, czyli nie obejmują wszystkich dyscyplin. Osadzone są w poszczególnych dziedzinach, towarzystwach naukowych lub obowiązują w danym czasopiśmie. Najczęstszym punktem odniesienia dla wielu dziedzin stały się rekomendacje dotyczące artykułów medycznych. International Committee of Medical Journal Editors (ICMJE) proponuje, żeby kwestie autorstwa rozstrzygać na podstawie czterech łącznych kryteriów:

1. Znaczący wkład w koncepcję lub projekt utworu; lub pozyskiwanie, analizę, lub interpretację danych do pracy; ORAZ

2. Opracowanie pracy lub krytyczny jej przegląd pod kątem ważnych treści intelektualnych; ORAZ

3. Ostateczne zatwierdzenie wersji, która zostanie opublikowana; ORAZ

1 Miejsce ostatnie w niektórych dziedzinach i środowiskach przeznaczano dla szefów zespołów. 
4. Zgoda na ponoszenie odpowiedzialności za wszystkie aspekty pracy w celu zapewnienia, że pytania dotyczące dokładności lub integralności jakiejkolwiek części pracy są odpowiednio badane i rozwiązywane.

Poza tym każdy współautor powinien być gotowy wskazać, która osoba jest odpowiedzialna za którą część pracy. Przy czym kryteria te nie mają na celu dyskwalifikować ludzi spośród współautorów, dlatego podkreśla się, żeby wszystkie osoby, które spełniają pierwsze kryterium, miały możliwość uczestniczenia w przeglądzie, opracowaniu i ostatecznym zatwierdzeniu manuskryptu (ICMJE 2019: 2, tłum. własne).

Wytyczne American Psychological Association (APA) (2020), które są punktem odniesienia dla nauk społecznych, również podkreślają konieczny udział autora na początku, czyli w projektowaniu badania, w środku, czyli w pisaniu artykułu, i na końcu, czyli w zatwierdzeniu całości do publikacji. Zasadniczo chodzi więc o udział zarówno w samym wysiłku pracy, jak i w procesie podejmowania decyzji. Jednocześnie wytyczne APA wyraźnie mówią, że w artykułach związanych z doktoratem, doktorant powinien być pierwszym autorem. W kwestii oceny znaczenia względnego wkładu studentów wytyczne odsyłają do opracowań interpretujących próby ich wdrażania (Fisher 2017), co - poza wyjaśnieniem, że na etapie przed-doktorskim współpraca studentów z pracownikami ma charakter praktykowania - sprowadza się ostatecznie do analizy konkretnych przypadków-precedensów (Fine, Kurdek 2010).

Powyższe kryteria publikowane są jako wytyczne dla osób starających się opublikować artykuł naukowy i stają się standardem, ponieważ obowiązują w wielu czasopismach $^{2}$. Z kolei z perspektywy badaczy są to tylko zalecenia, gdyż nie wyrastają z praktyki. Ta odbiega bowiem od postulatów (Shapiro 1994; Shaw 2011). Dlatego artykuły wskazujące rozwiązania warte upowszechnienia z punktu widzenia redakcji czasopism posługują się terminem odpowiedzialnego autorstwa (Horner, Minifie 2011; Moffatt 2011). Uzupełnieniem zagadnienia identyfikacji współtwórcy jest problem kryteriów wyłaniania tego głównego.

Nie da się po samej kolejności nazwisk na liście autorów artykułu jednoznacznie stwierdzić, kto co robił. Redakcje czasopism nie ingerują zwykle w podaną kolejność, gdyż jest to odpowiedzialność tych, którzy składają artykuł, a nie tych, którzy go publikują. Za anarchistami metodologicznymi można więc przyjąć, że „wszystko ujdzie" (Feyerabend 1993) do czasu, aż coś zacznie zależeć od tego ustawienia i sami współautorzy zaczną domagać się zmian w tym, co opublikowano. Roszczenia do współautorstwa lub do pozycji głównego, czyli pierwszego autora, mogą wynikać z tego, że dana praca może służyć im w zdobyciu grantu, pozycji społecznej, uznania autorstwa jakiejś koncepcji lub jako sposób naliczania cytowań (cytowanie artykułu, którego nie jest się głównym autorem, nie zawsze jest traktowane jako autocytowanie).

2 Ujednolicenie standardów odbywa się przez przystępowanie czasopism do członkostwa w Committee on Publication Ethics (COPE). Na forum tej organizacji między innymi rozstrzygane są kwestie sporne. 
Gdyby pominąć na chwilę problem walki o widoczność nazwisk badaczy ze względu na rywalizację o ograniczone fundusze na badania, to warto rozważyć, czemu jeszcze może służyć znormalizowane podpisywanie prac naukowych. Pojawienie się danego nazwiska w określonej pozycji listy współautorów mogłoby być sygnałem tego, o jakim aspekcie danego badania warto z daną osobą rozmawiać. Ale metodologie są różne i nawet osoba zajmująca się statystyką nie ma przypisanej pozycji na liście. Poza tym wiele czasopism wprowadziło instytucję autora korespondującego, który odpowiada za kontakt z redakcją i wszelką korespondencję na temat opublikowanego artykułu.

Można na problem właściwie porządkowanej listy współautorów spojrzeć jak na zagadnienie wiarygodności samych badań. Jako społeczność badaczy nie chcemy (a w szczególności nie chcą tego redaktorzy czasopism), żeby artykuły naukowe były produkowane przez niezidentyfikowane podmioty, potencjalnie uwikłane w konflikty interesów. O randze tych obaw niech świadczy to, że od autorów oczekuje się lub wprost wymaga się, by ujawnili źródła finansowania. Stąd też instrukcje nakazujące dbałość o to, żeby ujawniać wkład wszystkich osób pracujących (Sauermann, Haeussler 2017). Zmniejsza to ryzyko wystąpienia autora-ducha, czyli osoby o nieokreślonych kwalifikacjach, afiliacji i motywacjach, która napisałaby tekst na zlecenie nominalnego twórcy. Ujawnianie pracy wszystkich osób sprzyja studentom, gdyż jeśli wzięli udział w początkowej części badania, to - zgodnie z wytycznymi ICMJE oraz APA - powinni zachować możliwość uczestnictwa i wniesienia wkładu w dalszy ciąg przedsięwzięcia.

\section{Bariery współpracy}

Pewną odmianą kwestii wiarygodności jest problem czytelników z wyobrażeniem sobie tego, jak współautorzy pracowali ze sobą. W szczególności tego, na ile twórcy są w stanie wziąć odpowiedzialność za całość przedstawianych przez siebie treści. W niektórych przypadkach - szczególnie w związku z licznymi współautorami i różnie oznaczanymi wolontariuszami biorącymi udział w badaniach w ramach nauki obywatelskiej - ogląd całości przez pojedynczego twórcę może okazać się niemożliwy. Ignorując ważny, lecz graniczny przypadek niewystarczających kompetencji dla zrozumienia tego, czego jest się współautorem, za podstawową barierę rozumienia całości można uznać liczność grupy współautorów. Ich możliwa do „udźwignięcia” (poznawczo i komunikacyjnie) liczba będzie konsekwencją przyjętego sposobu komunikowania się w tym zespole, a zatem przyjętego modelu współpracy. 

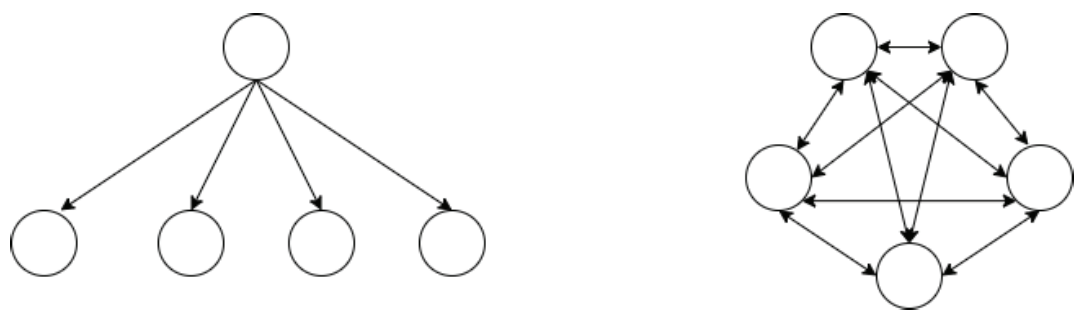

Rysunek 1. Warianty komunikacji w grupie. Przypadki skrajne ze względu na wielość komunikatów. Okręgi symbolizują osoby współpracujące; strzałki - komunikaty; strzałki obustronne - wymianę komunikatów

Źródło: opracowanie własne.

Należy zauważyć, że zasadniczo różnią się od siebie sytuacje, w których współautorzy w procesie tworzenia komunikują się tylko z jedną osobą odpowiadającą za całość, od tych sytuacji, w których komunikują się wszyscy ze wszystkimi (zob. rysunek 1). Można powiedzieć, że przypadek drugi, czyli współpraca wymagająca intensywnej komunikacji, wymaga większej „pojemności” dla zachodzących wewnątrz grupy procesów. Biorę więc pod uwagę trzy typy współpracy (Amici, Bietti 2015; Kowzan 2018; Pollard 2005; Zomorrodian 2011), czyli koordynację, kooperację i kolaborację między wykładowcami i studentami jako współautorami tekstu naukowego ${ }^{3}$. Nie uwzględniam tu zróżnicowania form zajęć, podczas których ta współpraca mogłaby się odbywać, to znaczy w ramach seminarium lub wykładu, ponieważ opracowywałem to zagadnienie w innym artykule (Kowzan 2017).

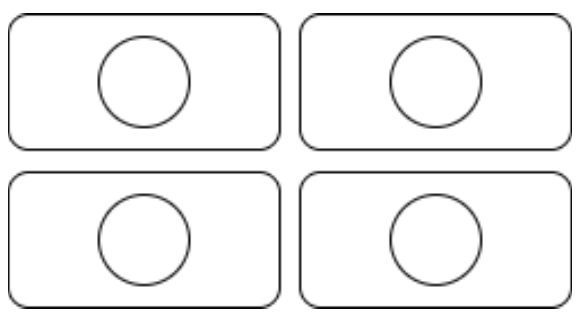

Rysunek 2. Koordynacja - parcelacja terytorium. Okręgi symbolizują osoby, a prostokąty - oddzielne zadania, za które odpowiedzialna jest dany członek zespołu

Źródło: opracowanie własne.

3 Podział współpracy na kolaborację, kooperację i koordynację jest obecny w naukach o zarządzaniu (Thomson, Perry 2006). W żadnym z dotychczasowych opracowań dotyczących współpracy w nauce nie znalazłem jego zastosowania. Badania o charakterze epistemologicznym ignorują relacje władzy wynikające z hierarchii (zob. Andersen 2016), badania socjometryczne koncentrują się na wytworach współpracy, a badania etnograficzne, które mogłyby dostarczyć przykładów tej analizie, pozostają osadzone w materialnej specyfice danej dyscypliny. Opis konsekwencji kolaboracji, kooperacji i koordynacji inspirowany jest badaniami z nurtu PAR, gdzie kwestie etyczne ogniskują się wokół form współpracy między współbadaczami, wyzysku wiedzy oraz instytucjonalnego wymogu pozbawienia współpracowników możliwości współautorstwa dysertacji (Klocker 2012). 
W przypadku koordynacji praca nad całością badania i publikacji zostaje zaplanowana $\mathrm{z}$ wyprzedzeniem, a zadania są rozdzielone i przypisane poszczególnym osobom (zob. rysunek 2). Praca poszczególnych osób nie zakłóca przebiegu pracy pozostałych, ponieważ zasadniczo ma ona charakter indywidualny. Koordynator dba o wartość dodaną, wynikającą ze złożenia poszczególnych wysiłków w spójną całość. Funkcję tę pełni na ogół wykładowca, a poszczególne zadania przypisane są studentom. Jest to model współpracy stosunkowo łatwy, zwłaszcza że wkład pracy uczniów może być elementem rozliczenia z zajęć, jako zaliczenie. Jako badacze koordynacją możemy być zainteresowani wtedy, gdy jakaś część procesu badawczego jest $z$ jednej strony zbyt pracochłonna i wymaga zaangażowania wielu osób, a zarazem jest na tyle pouczająca, że może stanowić ważne doświadczenie dydaktyczne dla studentów. Dla nich jest to zrozumiała formuła współpracy, gdyż zasadniczo nie odbiega od tego, czego doświadczają w ramach regularnych zajęć. Nawet mglista perspektywa zostania współautorami tekstu naukowego jest wówczas miłym dodatkiem na zakończenie zajęć. Studenci nie ponoszą jednak znacząco dodatkowego wysiłku na rzecz osiągnięcia tego celu.

Problemem pozostaje kwestia ich udziału w projektowaniu procesu badawczego, co jest jednym z kryteriów uznania wkładu pracy za autorstwo artykułu. W niektórych przypadkach jest zapewne możliwe, by studenci projektowali badanie w ramach zajęć i dyskutowali nad kwestiami metodologicznymi. Jest to zgodne z wytycznymi, ale zajmuje czas potrzebny do realizacji tego procesu. Zdecydowanie łatwiej jest wyznaczyć cel badań przed rozpoczęciem zajęć, zawęzić problemy metodologiczne badania do kwestii szczegółowych - ważnych, lecz nie decydujących o losie przedsięwzięcia. Na ogół nie ma pewności co do kompetencji badawczych studentów. Wiadomo, że raczej są zróżnicowane. Powierzamy więc zwłaszcza im zadania najprostsze, pozostawiając otwarte możliwości poziomu zaawansowanego. Można przyjąć, że podstawowym wymogiem jest zbieranie danych. Ich jakość bywa zróżnicowana, ale ilość pozwala pominąć słabsze próbki z analiz. Te natomiast okazują się zwykle pomocnym materiałem w procesie dydaktycznym, w celu omówienia problemów badawczych.

Wydaje się, że o włączeniu studentów do grona współautorów badania często decyduje ich udział w analizie zebranego materiału. To, co powstaje na tym etapie pracy, ma szanse zostać wykorzystane jako surowiec, to znaczy fragment surowej wersji artykułu. O ile proces zbierania materiału badawczego można było potraktować jako koordynowanie indywidualnych wysiłków, o tyle w przypadku analizy sprawy się komplikują. Studenci mogą analizować cały zebrany materiał lub jedynie swoją partię. Gdy priorytetem jest badanie, koordynatorom zależeć będzie na tym, by jak najwięcej pracy wykonano razem, czyli wszyscy partycypujący studenci będą analizować całość materiału. Wkład pracy poszczególnych osób w takim wariancie może zacząć się mocno różnicować, co stać się może podstawą do rozstrzygania o kolejności występowania na liście współautorów badania. Natomiast wariant $\mathrm{z}$ utrzymaniem rozdzielenia analizy pomiędzy poszczególne osoby lub małe grupy 
jest mniej satysfakcjonujący badawczo, gdyż zadanie scalania analiz koordynatorzy będą musieli wykonać sami.

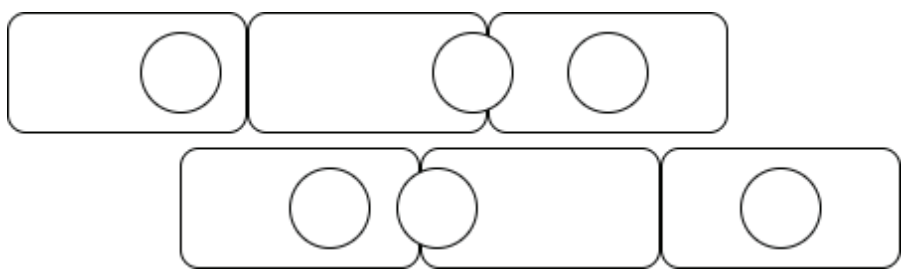

Rysunek 3. Kooperacja - funkcjonalnie powiązane zadania. Okręgi symbolizują osoby, a ich rozmieszczenie na prostokątach cząstkową odpowiedzialność i wkład w wykonanie zadania

Źródło: opracowanie własne.

Z kooperacją mamy do czynienia, gdy daną pracę może wykonać ktokolwiek z zespołu i nie ma terytoriów samodzielnej odpowiedzialności (zob. rysunek 3). Przykładowo, wprowadzając zmiany w tekście wspólnego artykułu, nie trzeba oglądać się na to, czyj to wkład pracy. Tego typu projekty są zazwyczaj wcześniej przygotowane, na przykład rozpisane są szczegółowo oczekiwania i procedury, których należy się trzymać, wykonując dane zadanie. Ten naddatek biurokracji ma zapobiec sytuacjom, w których ktoś wykonałby daną pracę nienależycie, a do zrozumienia niepisanych reguł potrzebowałby wprowadzenia przez kogoś pilnującego jakości wykonania tego zadania. O ten typ współpracy łatwo w przypadku, gdy wyrasta ona z projektu finansowanego z grantu. Organizacja dystrybucji środków na badania oraz konkurencja w tym zakresie powodują, że wnioski grantowe, szczególnie te z programów ramowych Unii Europejskiej, są uszczegółowione tak, by w razie przyznania finansowania mogły je zrealizować inne osoby niż zakładał to pierwotny wniosek. Skutkiem tego zadania są opisane zanim ludzie przystąpią do pracy. Ten ich szczegółowy opis stwarza warunki do tego, by także osoby o niższych kwalifikacjach mogły je wykonać wystarczająco dobrze. Twórcy o wyższych kwalifikacjach mogą być niechętni do tego typu współpracy - zbiurokratyzowanie procesu pracy może odbierać im poczucie własnej sprawczości, ponieważ trudno jest indywidualnie interweniować w przebieg realizacji zaplanowanych procesów. W kooperacji liczy się sprawność realizacji. Każdą pracę powinien móc wykonać ktokolwiek, a poszczególne zadania nie mogą być postrzegane jako zajęcia niegodne. 


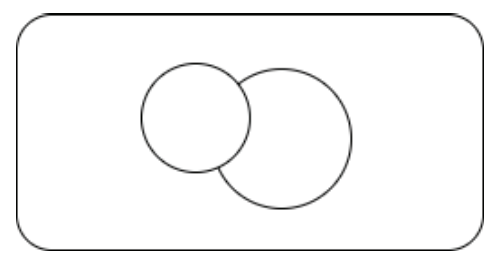

Rysunek 4. Kolaboracja - asymetryczny konflikt w ramach zadania. Okręgi różnej wielkości symbolizują zróżnicowany potencjał osób, a nachodzenie ich na siebie - konflikt

Źródło: opracowanie własne.

Trzeci typ współpracy to kolaboracja (zob. rysunek 4), która polega na realizacji wspólnego celu poprzez ścieranie się osób o asymetrycznym statusie. Sprzeczne interesy, punkty widzenia lub wartości w jednym zespole mają wywołać konflikt, który - jeśli okaże się twórczy - stwarza szanse na przełomowe osiągnięcia. Sytuacja taka w badaniach naukowych dotyczyć może współpracy osób z różnych dziedzin lub studentów z wykładowcami. Powodzenie takich działań zależy od tego, w jakim stopniu opinie i wkład osób słabszych w tej relacji będą z jednej strony artykułowane, a z drugiej - uwzględniane. Ten typ współpracy, w stosunku do pozostałych, ma największy potencjał wytworzenia zdarzeń przełomowych, wymykających się wcześniejszym kalkulacjom. Świadomi tego potencjału wykładowcy w relacji ze studentami będą dążyli do stworzenia warunków, w których nie będą oni czuli się skrępowani zabieraniem głosu. Nie oznacza to jedynie wytwarzania egalitarnych stosunków międzyludzkich, ale także - wręcz przeciwnie - posługiwanie się „nauczycielską przemocą” (zob. Zamojski 2019) w jego wymuszaniu. Robi się to wszystko w celu przyzwyczajenia słabszej strony do tego, że udana współpraca wymaga od niej zabierania głosu. Samo tylko uprawianie egalitaryzmu nie musi do tego prowadzić. Jeżeli nie pojawia się osąd przeciwny, to można mieć wątpliwości co do tego, że atmosfera jest dość egalitarna albo że słabsza strona dysponuje spodziewanym potencjałem.

Sposób przejścia między typem współpracy a wytycznymi współautorstwa zależy głównie od szefa zespołu (jeśli taki jest). Niektóre kryteria autorstwa jednak łatwiej spełniać w określonych warunkach. Próbując określić szanse (+) wypełnienia i zagrożenia (-) niespełnieniem tych wytycznych przez każdą z osób zaangażowanych w badanie, wziąłem pod uwagę sytuacje, w których uczestników cechuje zaangażowanie we współpracę i etyczne postępowanie, czyli na przykład składanie prawdziwych oświadczeń. 
Tabela 1. Szanse i zagrożenia dla wypełnienia kryteriów autorstwa ICMJE wobec różnych sposobów organizacji współpracy badawczej, gdzie (+) oznacza szanse, (-) zagrożenia, a (+/-) sytuację niejasną

\begin{tabular}{|l|c|c|c|}
\hline \multicolumn{1}{|c|}{ Wytyczne } & \multicolumn{2}{c|}{ Współpraca } \\
\cline { 2 - 4 } & Koordynacja & Kooperacja & Kolaboracja \\
\hline $\begin{array}{l}\text { 1. Znaczący wkład w koncepcję lub projekt utworu; } \\
\text { lub pozyskiwanie, analizę, lub interpretację danych do } \\
\text { pracy }\end{array}$ & - & $+/-$ & + \\
\hline $\begin{array}{l}\text { 2. Opracowanie pracy lub krytyczny jej przegląd pod } \\
\text { kątem ważnych treści intelektualnych }\end{array}$ & + & $+/-$ & + \\
\hline $\begin{array}{l}\text { 3. Ostateczne zatwierdzenie wersji, która zostanie } \\
\text { opublikowana }\end{array}$ & - & $+/-$ & + \\
\hline $\begin{array}{l}\text { 4. Zgoda na ponoszenie odpowiedzialności za } \\
\text { wszystkie aspekty pracy }\end{array}$ & - & + & $+/-$ \\
\hline
\end{tabular}

Źródło: opracowanie własne.

I tak, pracując w warunkach napięcia, a niekiedy wręcz konfliktu, charakterystycznych dla kolaboracji, wszystkie zaangażowane osoby mają szanse na znaczący wkład na trzech etapach pracy (koncepcja, opracowanie, zatwierdzenie), a jednocześnie poszczególne aspekty wytworzonego artykułu mogą wydawać się im obce. Na przeciwległym biegunie jest praca w warunkach koordynacji, gdyż dla studentów stwarza ona zagrożenie, że zostaną pominięci w projektowaniu badania i zatwierdzaniu ostatecznej wersji artykułu, a co za tym idzie - nie będą odpowiedzialni za całość pracy. Za to w wyznaczonych wszystkim działkach każdy uczestnik ma szansę wnieść znaczący intelektualnie wkład pracy. Najwięcej niepewności jest przy szacowaniu a priori ryzyka w przypadku kooperacji, gdyż praca może zostać podzielona na małe części tak, że choć uczestnicy będą panować nad całością, to ich rozproszone serie mikro-wkładów nie dadzą im poczucia indywidualnego znaczenia.

W literaturze przedmiotu (Fine, Kurdek 2010; Scassa, Chung 2015) zaleca się ustalanie współautorstwa przed pracą, ale wówczas nie wiadomo jeszcze nic o jej przebiegu (Maurer 2017). Wiele wspólnie rozpoczętych projektów nie kończy się publikacją lub nawet nie dochodzi do skutku, gdyż były właśnie zaledwie projektami. Proces publikacji bywa czasochłonny i niektórzy jego uczestnicy mogą stracić nim zainteresowanie. Dzieje się tak zwłaszcza w przypadku studentów, którzy kończą edukację.

\section{Podsumowanie}

Dla osób zatrudnionych do prowadzenia badań współpraca z ludźmi, którzy zajmują się tym incydentalnie, nie jest sytuacją ani etycznie oczywistą, ani łatwą. Decydując się na współpracę, profesjonaliści muszą, prędzej lub później - czyli projektując badanie lub przygotowując publikację - rozwiązać kilka dylematów. Spośród nich kwestia autorstwa i organizacji współpracy wydają się interesująco splecione, gdy 
uwzględni się wytyczne towarzystw naukowych dotyczących tego, komu można przypisać autorstwo artykułu, kogo wymienić w podziękowaniach, a czyj wkład można pominąć. Opisana w artykule specyfika koordynacji, kooperacji i kolaboracji pokazała ich ograniczenia w kontekście pracy badawczej. I choć ta typologia wymaga empirycznej weryfikacji, może ona - wraz z zestawieniem szans i zagrożeń poszczególnych rozwiązań - stanowić podstawę schematu podejmowania decyzji o sposobie organizacji takiej współpracy badawczej lub o przystąpieniu do zespołu. Dzięki typologii współpracy studenci, którzy na ogół jej rodzaju nie ustalają, gdyż jej nie inicjują, mają szansę rozpoznać proponowany im typ i ocenić swoje w nim szanse. Jeżeli chce się spełniać kryteria autorstwa, trzeba artykułować własne zdanie, gdyż jest to podstawowy wymóg przy kolaboracji. Jeżeli podczas badań jest się osobą, która samodzielnie wykonuje jedno zadanie na rzecz wspólnego artykułu, to szanse na spełnienie kryteriów autorstwa są niewielkie.

Dalszych badań wymaga to, na ile można wyodrębnić powyższe typy współpracy w praktyce badawczej i jak trwały jest to porządek na dystansie pojedynczego projektu badawczego. Dzięki temu będzie można określić użyteczność przedstawionego modelu w przewidywaniu tego, w jakich warunkach zostaje się współautorką/-em publikacji, a kiedy zasługuje się zaledwie na podziękowania. Warto też monitorować, jak nierówności między współpracującymi osobami oraz problemy autorstwa narastają w kontekście post-humanizmu, czyli na przykład wtedy, gdy badacze zaczną wspierać się w swojej pracy twórczej asystentami wyposażonymi w tak zwaną sztuczną inteligencję, których rosnące możliwości intelektualne mogą stać się trudno odróżnialne od indywidualnej autonomii.

\section{Literatura}

Ackerman M., Brânzei S., 2017, The Authorship Dilemma: Alphabetical or Contribution?, "Autonomous Agents and Multi-Agent Systems” vol. 31, iss. 5.

American Psychological Association, 2020, Publication manual of the American Psychological Association, Washington: American Psychological Association.

Amici F., Bietti L.M., 2015, Coordination, collaboration and cooperation. Interdisciplinary perspectives, „Interaction Studies” vol. 16, iss. 3.

Andersen H., 2016, Collaboration, interdisciplinarity, and the epistemology of contemporary science, „Studies in History and Philosophy of Science” vol. 56.

Bornowska K., Jendza J., Zamojski P., 2009, Ambiwalencja selekcji w szkole wyższej - raport z badań. (Na przykładzie kwestii jakości kształcenia pedagogów), „Problemy Wczesnej Edukacji” nr 9.

Brabazon T., 2016, Winter is Coming: Doctoral Supervision in the Neoliberal University, „International Journal of Social Sciences \& Educational Studies” vol. 3, iss. 1.

Bruno B., 2014, Economics of co-authorship, „Economic Analysis and Policy” vol. 44, iss. 2.

Costa M.M., Gatz M., 1992, Determination of authorship credit in published dissertations, „Psychological Science” vol. 3, no. 6. 
Červinková H., 2013, Etnografia edukacyjna i badania w działaniu - z warsztatu kształcenia nauczycieli, „Forum Oświatowe” nr 1.

Deesomsak R., Paudyal K., Pescetto G., 2014, Durham Research Online woodlands, „Critical Studies on Security" vol. 2, iss. 2.

Ductor L., 2015, Does co-authorship lead to higher academic productivity?, „Oxford Bulletin of Economics and Statistics" vol. 77, iss. 3.

Erren T.C., Groß J.V., Wild U., Lewis P., Shaw D.M., 2017, Crediting animals in scientific literature, „EMBO Reports” vol. 18, iss. 1.

Feyerabend P., 1993, Against method, London-New York: Verso.

Fine M.A., Kurdek L.A., 2010, Reflections on determining authorship credit and authorship order on faculty-student collaborations, „American Psychologist” vol. 48, no. 11.

Fisher C.B., 2017, Decoding the Ethics Code: A Practical Guide for Psychologists, Los Angeles-London-New Delhi-Singapore-Washington DC-Melbourne: Sage Publications.

Geminiani A., Ercoli C., Feng C., Caton J.G., 2014, Bibliometrics Study on Authorship Trends in Periodontal Literature From 1995 to 2010, „Journal of Periodontology” vol. 85, iss. 5.

Goodyear R.K., Crego C.A., Johnston M.W., 1992, Ethical Issues in the Supervision of Student Research: A Study of Critical Incidents, „Professional Psychology: Research and Practice” vol. 23 , no. 3 .

Hardt M., 2012, Praca afektywna, tłum. P. Juskowiak, K. Szadkowski, „Kultura Współczesna" nr 3.

Horner J., Minifie F.D., 2011, Research ethics III: Publication practices and authorship, conflicts of interest, and research misconduct, "Journal of Speech, Language, and Hearing Research" vol. 54, iss. 1.

Hurmelinna-Laukkanen P., Alexander A., Papageorgiou K., Daellenbach U., 2019, The Promiscuity of Publishing Partners in Innovation Management Research - The formation and impact of publishing collaborations, https://ore.exeter.ac.uk/repository/bitstream/ handle/10871/36163/30011.pdf? sequence=1\&isAllowed=y [dostęp: 10.09.2019].

International Committee of Medical Journal Editors, 2019, Recommendations for the conduct, reporting, editing, and publication of scholarly work in medical journals, http:// www.icmje.org/recommendations/ [dostęp: 1.10.2019].

Jeran A., Basińska A., 2020, Clinical research Edgara H. Scheina - badanie kultury organizacyjnej między metodyka psychologii, socjologii i antropologii, „Przegląd Socjologii Jakościowej" t. 16, nr 3.

Kadel A., Walter A., 2015, Do scholars in Economics and Finance react to alphabetical discrimination?, „Finance Research Letters” vol. 14.

Klocker N., 2012, Doing Participatory action research and Doing a PhD: Words of encouragement for prospective students, „Journal of Geography in Higher Education” vol. 36, no. 1.

Kowzan P., 2017, Dydaktyka zorientowana na wspótpracę równych. Typy relacji ze studentami podczas wspólnej pracy badawczej, „Hybris” nr 36.

Kowzan P., 2018, Edukacja wobec groźby wojny, „Parezja. Czasopismo Forum Młodych Pedagogów Przy Komitecie Nauk Pedagogicznych PAN” nr 1.

Kowzan P., Krzymiński D., Hurko K., Życzyńska J., Koenig M., Bloch P., Rainka D., Mojzykiewicz M., Bigus W., 2018, Protestujące dzieci, „Teraźniejszość-Człowiek-Edukacja. Kwartalnik Myśli Społeczno-Pedagogicznej” nr 1.

Kowzan P., Zielińska M., 2016, Pochłaniacze czasu - doktorzy na uczelniach w Polsce wobec organizacji czasu ich pracy, „Nauka i Szkolnictwo Wyższe” nr 2. 
Kwiek M., 2019a, Globalna nauka: dlaczego jej istotą sa nierówności (i co z tego wynika dla młodych naukowców), wykład inauguracyjny, Center for Public Policy Studies, http:// cpp.amu.edu.pl/pl/new-amu-doctoral-school-for-600-phds-opened-inaugural-keynote-speech-by-marek-kwiek/ [dostęp: 31.01.2019].

Kwiek M., 2019b, Indywidualna produktywność naukowa i konsekwencje rosnącej stratyfikacji społecznej w nauce, Poznań: Centrum Studiów nad Polityką Publiczną UAM.

Mason-Deese L., Dalton C., Swanson N., Stallmann T., Casas-Cortes M., Cobarrubias S., 2018, Counter-Mapping Militant Research [w:] This Is Not an Atlas: A Gobal Collection of Counter-Geographies, ed. kollectiv orangotango+, Bielefeld: transcript Verlag.

Maurer T.W., 2017, Guidelines for authorship credit, order, and co-inquirer learning in collaborative faculty-student SOTL projects, „Teaching and Learning Inquiry” vol. 5, no. 1. Mercer-Mapstone L., Dvorakova S.L., Matthews K.E., Abbot S., Cheng B., Felten P., Knorr K., Marquis E., Shammas R., Swaim K., 2017, A Systematic Literature Review of Students as Partners in Higher Education, „International Journal for Students as Partners” vol. 1, iss. 1.

Min S.-K., 2019, Unjustified Authorship such as Gift Authorship for Your Kids: It Is a Crime, Professor, „Vascular Specialist International” vol. 35, iss. 4.

Moffatt B., 2011, Responsible authorship: Why researchers must forgo honorary authorship, „Accountability in Research” vol. 18, iss. 2.

Moustafa K., 2016, Contributorships Are Not “Weighable” to be Equal, „Trends in Biochemical Sciences" vol. 41, iss. 5.

Naezer M., Benschop Y., van den Brink M., 2019, Harassment in Dutch academia. Exploring manifestations, facilitating factors, effects and solutions, Utrecht: LNVH.

Pollard D., 2005, Will That Be Coordination, Cooperation, or Collaboration?, How to save the world, http://howtosavetheworld.ca/2005/03/25/will-that-be-coordination-cooperation-or-collaboration [dostęp: 1.10.2019].

Robertson J., 2007, Beyond the 'research/teaching nexus': exploring the complexity of academic experience, „Studies in Higher Education” vol. 32, iss. 5.

Sauermann H., Haeussler C., 2017, Authorship and contribution disclosures, „Science Advances" vol. 3, no. 11.

Scassa T., Chung H., 2015, Typology of Citizen Science Projects from and Intellectual Property Perspective: Invention and Authorship Between Researchers and Participants, „Policy memo series” vol. 5, Wilson Center, http://www.wilsoncenter.org/publication/typology-citizen-science-projects-intellectual-property-perspective [dostęp: 11.09.2019].

Shapiro D.W., 1994, The contributions of authors to multiauthored biomedical research papers, "The Journal of the American Medical Association” vol. 271, iss. 6.

Shaw D., 2011, The authorless paper, „British Medical Journal” vol. 343, iss. 7831.

Sikes P., 2009, Will the real author come forward? Questions of ethics, plagiarism, theft and collusion in academic research writing, „International Journal of Research and Method in Education" vol. 32, iss. 1.

Smith E., Williams-Jones B., Master Z., Larivière V., Sugimoto C.R., Paul-Hus A., Shi M., Diller E., Caudle K., Resnik D.B., 2020, Researchers' Perceptions of Ethical Authorship Distribution in Collaborative Research Teams, „Science and Engineering Ethics” vol. 26, iss. 4 .

Szadkowski K., 2015, Postoperaistyczne spojrzenie na prace produkcyjna i nieprodukcyjna w nauce i szkolnictwie wyższym, „Praktyka Teoretyczna” t. 18, nr 4. 
Szwabowski O., Wężniejewska P., 2017, An (co)autoethnographic story about going against the neoliberal didactic machine, "Journal for Critical Education Policy Studies” vol. 15, iss. 3.

Tight M., 2016, Examining the research/teaching nexus, „European Journal of Higher Education" vol. 6, iss. 4.

Thomson A.M., Perry J.L., 2006, Collaboration Processes: Inside the Black Box, „Public Administration Review" vol. 66, iss. s1.

Tsai C.C., Corley E.A., Bozeman B., 2016, Collaboration experiences across scientific disciplines and cohorts, „Scientometrics” vol. 108, iss. 2.

Victor B.G., Hodge D.R., Perron B.E., Vaughn M.G., Salas-Wright C.P., 2017, The rise of co-authorship in social work scholarship: A longitudinal study of collaboration and article quality, 1989-2013, „British Journal of Social Work” vol. 47, iss. 8.

Youtie J., Bozeman B., 2016, Dueling Co-Authors: How Collaborators Create and Sometimes Solve Contributorship Conflicts, „Minerva” vol. 54, iss. 4.

Zamojski P., 2019, Ponieważ sprawy sa ulotne, trzeba mieć wprawne oko, „Ars Educandi” nr 16. Zomorrodian A., 2011, New approach to strategic planning: The impact of leadership and culture on plan implantation via the three Cs: Cooperation, collaboration and coordination, „ASBBS Annual Conference” vol. 18, iss. 1.

\section{Streszczenie}

Celem artykułu jest identyfikacja takich rozwiązań organizacyjnych w zakresie współpracy badawczej ze studentami, które byłyby etyczne z perspektywy późniejszego współautorstwa artykułów i korzystne - zarówno dla studentów, jak i dla pracowników naukowo-dydaktycznych. W tym celu rozpatrzymy trzy różne modele współpracy (koordynację, kooperację i kolaborację), które w określony sposób porządkują relacje w zespole. Rozpatrzymy możliwości i ograniczenia tych modeli na tle współczesnych wyzwań pracy akademickiej i formalnych wymagań dotyczących współautorstwa artykułów. Rezultatem będzie zestawienie szans i zagrożeń poszczególnych rozwiązań, które wraz z modelami współpracy badawczej mogą stanowić podstawę schematu podejmowania decyzji o sposobie organizacji takiej współpracy ze studentami.

\section{Słowa kluczowe}

etyka, standardy, współpraca badawcza, autorstwo

\section{Summary}

\section{Co-authorship: Exploitation and collaboration (with students)}

The goal of the article is to identify such organizational solutions in the field of research collaboration with students that would be ethical from the perspective of subsequent co-authorship of articles and beneficial to both students and academic staff. For this purpose, we consider three different models of working together (coordination, cooperation and collaboration) which organize relations in the team in a specific way. We consider the possibilities and limitations of these models against the background of contemporary 
challenges of academic work and formal requirements for co-authoring articles This will result in a comparison of the opportunities and threats of individual solutions, which - together with three models of organizing collective work - can form the basis of a decision-making scheme on how to organize such work with students.

\section{Keywords}

ethics, collaboration patterns, research collaboration, authorship 